\title{
Potential shift in tree species composition after interaction of fire and drought in the Central Alps
}

\author{
B. Moser · C. Temperli • G. Schneiter • \\ T. Wohlgemuth
}

Received: 10 August 2009/Revised: 6 January 2010/ Accepted: 5 February 2010/Published online: 27 February 2010

(C) Springer-Verlag 2010

\begin{abstract}
The future trajectory of forest ecosystems under climate change is heavily debated. Previous studies on the impacts of climate change on forest ecosystems have focused mainly on direct effects of altered climatic conditions, whereas interactions with disturbance events have been largely neglected. The aim of this study is to explore interactions of drought with fire disturbance and to assess their effects on tree species shifts in the European Central Alps. Tree recruitment after a stand replacing wildfire in the Rhone valley, Switzerland, was measured along an altitudinal temperature moisture gradient. Recruitment was more successful in pioneer species (Betula pendula, Populus tremula and Salix appendiculata) than in pre-fire stand forming (PFSF) species (Larix decidua, Picea abies and Pinus sylvestris). Seedling and sapling density was not related to fire intensity, but it correlated with the distance to the forest edge in PFSF species. The window of opportunity for seedling establishment was short (1-2 years), and moisture deficit was the main limiting factor for tree recruitment at lower altitudes. We suggest that prolonged drought periods, as projected under continued global warming, will further aggravate tree recruitment success after fire disturbance at low altitudes of the Central Alps and may eventually lead to a shift from PFSF species to either more drought-tolerant species or to forest-free vegetation.
\end{abstract}

Communicated by J. Müller.

B. Moser $(\varangle)$ - C. Temperli · G. Schneiter · T. Wohlgemuth Disturbance Ecology, Swiss Federal Institute for Forest,

Snow and Landscape Research WSL, Zürcherstrasse 111, 8903 Birmensdorf, Switzerland

e-mail: barbara.moser@wsl.ch
Keywords Central Europe - Disturbance · Drought . Pine forest $\cdot$ Post-fire regeneration - Tree recruitment

\section{Introduction}

As a consequence of the projected long-term changes in temperature and precipitation fluctuations in Central Europe (Schär et al. 2004), climate envelope models predict major shifts of tree species' ranges both in latitude (Sykes et al. 1996; Thuiller 2003; Thuiller et al. 2006) and altitude (Brzeziecki et al. 1995; Sykes and Prentice 1996). Current evidence for future tree species' shifts is most often based on observed changes in growth rates (e.g. Jump et al. 2006), forest species composition (see review by Walther 2003), forest phenology (Badeck et al. 2004; Linderholm 2006) or tree-line movements (Kullman 2002; Payette et al. 1989), whereas reports on changes in tree recruitment are still sparse (Peñuelas et al. 2007). In practice, shifts of tree species in undisturbed forests are difficult to detect, and the speed and the magnitude of climate-induced range shifts or changes in forest species assemblages are heavily debated. Several authors suggest that increased temperatures alone will not fundamentally alter forest ecosystems, while interactions of climate change with disturbance events, by contrast, may trigger abrupt and irreversible changes in forest species composition (Chapin et al. 2004; Dale et al. 2001). The modelling study by Schumacher \& Bugmann (2006) predicts that increasing temperatures in combination with fire disturbance may become a major factor shaping Alpine forest ecosystems in the future. Similarly, Overpeck et al. (1990) suggest that increased disturbance frequencies accelerate forest vegetation responses to climate change in North America. Interactions of climate change with disturbance have been largely neglected in the 
prediction of the future trajectory of forest ecosystems, although some authors discussed the impact of shorter fire intervals on forest composition (Dale et al. 2001; Johnstone and Chapin 2006). However, fire may affect tree species composition much more directly and on a shorter time scale than through changes in fire frequency, e.g. by destroying the existing canopy and opening a window for the establishment of new species that are better adapted to modified climatic conditions (Overpeck et al. 1990; Tercero-Bucardo et al. 2007). Since fire frequency is currently low in Central European forests (Tinner et al. 2005), it has not been considered as important for shaping coniferous forest ecosystems as e.g. in North America (Attiwill 1994). Thus, forest gap initiation in combination with altered climatic conditions may be the main factor triggering tree species shifts in the European Alps in the short term.

Tree recruitment after fire disturbance depends on a variety of factors such as propagule availability, germination success and seedling survival and establishment (Rodríguez-Pérez and Traveset 2007). In coniferous species, propagule availability after a disturbance is primarily determined by the seed rain from live trees and the dispersal capacity of the seeds, whereas asexual reproduction and persistent seed banks are less common (Greene et al. 2005; Krüssmann 1983; Zasada et al. 1992), although aerial seed banks are known in some species (e.g. Picea mariana (Mill.) Britton et al. Pinus banksiana Lamb.; Greene and Johnson 2000). Depending on fire severity, a seedling and sapling bank may survive. In European conifers, seed germination and seedling survival after disturbance are generally thought to be favoured by a thin organic layer, exposed mineral soil and sufficient moisture (Brang 1998; Greene et al. 2005; Valkonen and Maguire 2005; Vanha-Majamaa et al. 1996), whereas the effect of mosses is not consistent (Hanssen 2003; Valkonen and Maguire 2005; Wohlgemuth et al. 2002). Studies at the southern distribution limit of Scots pine Pinus sylvestris L. suggest that long drought periods during the growing season, which are predicted to increase in Central Europe as a consequence of climate change (Schär et al. 2004; Schmidli and Frei 2005), may become a major threat to the establishment of conifer seedlings in Central Europe in the future (Castro et al. 2004; Castro et al. 2005).

The aim of this study is to assess whether interactions of fire disturbance with temperature and precipitation may accelerate climate-induced tree species shifts in forests of the dry valleys of the European Central Alps. We assessed recruitment success of different tree species after a stand replacing wildfire in the Valais, Switzerland, one of the driest regions in the Alps. Tree recruitment, air temperature and precipitation were quantified along an altitudinal gradient of 1,200 m (900-2,100 m a.s.l.), which corresponds to a temperature moisture gradient. We tested: (1) whether the recruitment success of pre-fire stand forming (PFSF) tree species increases with altitude, i.e. with increasing precipitation, (2) whether tree species other than PFSF species (e.g. pioneer species) successfully establish at low altitudes, i.e. under high temperatures and low precipitation and (3) whether seedbed conditions in terms of availability of exposed mineral soil and moss cover, distance to the live forest edge or fire severity are more important for tree regeneration after fire disturbance than temperature and precipitation.

\section{Materials and methods}

Study site

The study site is located near Leuk in the Central Alpine Rhone valley in the Valais, Switzerland $\left(46^{\circ} 20^{\prime} \mathrm{N}, 7^{\circ} 39^{\prime} \mathrm{E}\right.$; Fig. 1a). A wildfire started by arson in 2003 burnt 310 ha of forest along an altitudinal gradient of 1,200 m ranging from $900 \mathrm{~m}$ a.s.l. to the tree line at 2,100 $\mathrm{m}$ a.s.l (Fig. 1c). The pre-fire forest communities consisted of Scots pine Pinus sylvestris L. in the lower montane zone (9001,300 m a.s.1.), Norway spruce Picea abies (L.) H. Karst. in the upper montane zone (1,300-1,700 $\mathrm{m}$ a.s.l.) and mixed spruce and larch Larix decidua Mill. forest in the subalpine zone between 1,700 $\mathrm{m}$ a.s.l. and the tree line (Ott et al. 1997). The pre-fire vegetation also included a small proportion of downy oak Quercus pubescens Willd. in the lowest parts of the study site, but the main distribution of this species is below $900 \mathrm{~m}$ a.s.l. Apart from the area immediately adjacent to the burn edge and a small area (ca. 1 ha) of Norway spruce and larch that survived the fire at $1,750 \mathrm{~m}$ a.s.l., the understory vegetation as well as the foliage and fine twigs of all standing trees was completely consumed. The fire further destroyed $80 \%$ of the soil organic layer (Wohlgemuth et al. 2005).

The upper Rhone valley has a continental climate similar to that of the Briançonnais in France and the Val d'Aoste and Vinschgau in Italy (Zumbrunnen et al. 2009), which is characterised by low precipitation levels, especially during the summer months (average annual precipitation $637 \mathrm{~mm}$ at $539 \mathrm{~m}$ a.s.l.; meteorological station Sierre, MeteoSwiss). In comparison with southern European regions (e.g. the Mediterranean basin), the fire activity in the Rhone valley is currently rather low. Between 1904 and 2006, 129 fires/100 $\mathrm{km}^{2}$ of forest occurred below $1,400 \mathrm{~m}$ a.s.l., but only 40 fires $/ 100 \mathrm{~km}^{2}$ of forest were observed at higher altitudes (Zumbrunnen et al. 2009).

Tree recruitment survey

In 2004, 125 permanent sampling plots of $50 \mathrm{~m}^{2}$ were established on a systematic grid of $125 \mathrm{~m} \times 125 \mathrm{~m}$ within 

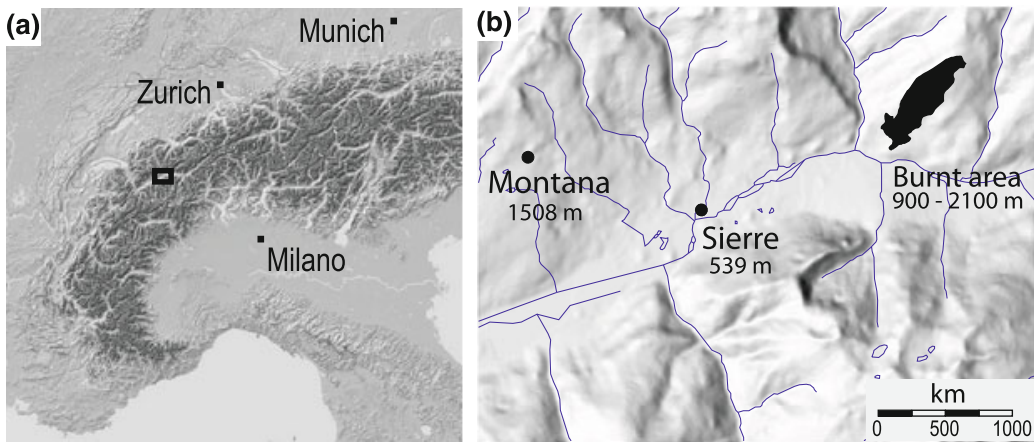

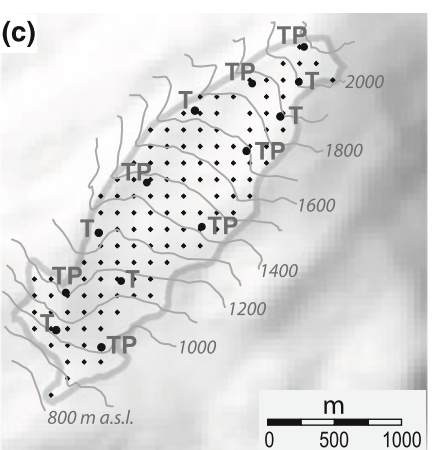

Fig. 1 a Location of the study site in the inner-alpine valley of the Valais, Switzerland. b Locations of the 310 ha burn near Leuk and the MeteoSwiss stations in Sierre (539 m a.s.1.) and Montana (1,508 m

the burnt area (Fig. 1c). Distances of the sampling plots to the nearest forest edge and/or the 1 ha within-burn zone where living trees remained vary between 3 and $463 \mathrm{~m}$. From 2004 to 2007, the number of seedlings $(0-10 \mathrm{~cm}$ height) and saplings (11-500 cm height) was recorded annually for each tree species during summer season (June-August). Seedling mortality was calculated from differences between years, taking into account seedlings grown into the sapling stage. The cover of mosses, herbaceous species and exposed mineral soil (with or without ash) were estimated using the decimal scale of Londo (1976). The thickness of the ash layer in 2004 (median of nine measurements/plot) was used as an index of fire intensity (Henig-Sever et al. 2001). Because the fire was severe throughout the entire burnt area and the crowns of all standing trees were completely scorched, we could not rely on crown scorch height or similar, more commonly used measurements of fire intensity. Annual records of cone production made by A. Burkart, Versuchsgarten WSL, in Graechen and Gampel Steg, two sites in the Rhone valley near Leuk, were used to estimate seed rain of Scots pine, Norway spruce and larch in the years following the fire (2004-2006).

\section{Climate data}

The climate along the altitudinal gradient was quantified using different data sources: (1) short-term monthly average temperatures and monthly average precipitation (20052007) measured within the burn at 13 temperature and 7 precipitation gauging stations, respectively, located along the altitudinal gradient (Fig. 1c) and (2) long-term monthly average precipitation (1931-2007) measured at two meteorological stations run by MeteoSwiss and located in the close vicinity of the burn, in Sierre (539 m a.s.1.) and Montana (1,508 $\mathrm{m}$ a.s.l.; Fig. 1b). Within the burn, temperature was measured with Thermochron iButtons (DS1922L with a resolution of $0.5^{\circ} \mathrm{C}$; Maxim Integrated a.s.1.). c Locations of the 125 sampling plots (small dots) and the 13 meteorological stations (large dots) measuring temperature (T) and precipitation $(\mathrm{P})$ within the burn

Products, Sunnyvale, USA) fixed in pairs under a sunshade at $2 \mathrm{~m}$ above soil level. Precipitation was measured annually from June to September using Campbell rain gauges. Precipitation measurements were not possible during months with snowfall, i.e. October to May at the highest gauging station.

A monthly drought index (DRI) was calculated according to Thornthwaite (1948): DRI $=\mathrm{P}-\mathrm{PE}$, with $\mathrm{P}$ equal to the monthly precipitation sum, and $\mathrm{PE}$ equal to the estimated potential evapotranspiration in the same month, a function of monthly mean temperatures and geographical latitude. Values of DRI below zero indicate moisture deficits. Bigler et al. (2006) evaluated different drought indices for the Rhone valley and found no differences between the simple index of Thornthwaite and more mechanistic ones.

Data analyses

The distribution of seedling and sapling density as well as the distribution of herbaceous vegetation along the altitudinal gradient was modelled with generalized additive models (GAMs) using the 'gam' function of the R 'mgcv' library with Gaussian error distribution. Generalized linear models (GLMs) were then used to investigate the relationship between tree recruitment (number of seedlings and saplings $0-500 \mathrm{~cm}$ ) in the first 4 years after the fire $(2004$ 2007) and the factors altitude ( $\mathrm{m}$ a.s.l.), availability of exposed mineral soil (\%), moss cover (\%), distance to the live forest edge (m) and thickness of the ash layer in 2004 $(\mathrm{cm})$. Since the response variable was discrete (number of seedlings and saplings $0-500 \mathrm{~cm}$ ), we fitted a GLM with Poisson distribution and $\log$ link. The predictors were standardised prior to the analysis. Stepwise model optimisation was used in order to select the most parsimonious model, i.e. variables were only added to the model if they were significant and the change in $D^{2}$ was $\geq 10 \%$. Following the distribution of pre-fire forest communities along 
the altitudinal gradient, seedling survival and mortality as well as the proportion of different tree species present in 2007 were calculated for each altitudinal zone (lower montane, upper montane and subalpine) separately. Linear regression was used to assess temperature and precipitation trends along the altitudinal gradient within the burn. The analysis focused on the spring months (April-June), the most important season for seedling establishment and tree growth in Scots pine and Norway spruce (e.g. Castro 2006; Pichler and Oberhuber 2007; Rigling et al. 2002). DRI's along the altitudinal gradient were calculated for the month of June only, because precipitation measurements were not possible in April and May. In contrast, long-term precipitation levels were analysed for the entire spring season as well as on an annual basis. Statistical analyses were done using the statistical computing system $\mathrm{R}$ Version 2.4.1 (R Development Core Team 2006).

\section{Results}

Tree recruitment along the altitudinal gradient

The density of tree seedlings and saplings $(0-500 \mathrm{~cm})$ per ha varied considerably along the altitudinal gradient with almost no seedlings below $1,100 \mathrm{~m}$ a.s.l. and a sharp increase above $1,600 \mathrm{~m}$ a.s.l. (Fig. 2a). In 2007, total numbers/ha $( \pm$ SE) averaged $590( \pm 148)$ in the lower montane zone $(900-1,299 \mathrm{~m}$ a.s.1.) and $696( \pm 139)$ in the upper montane zone $(1,300-1,699 \mathrm{~m}$ a.s.1.), whereas an average of 2,821 $( \pm 701)$ seedlings and saplings/ha were found in the subalpine zone (1,700-2,100 $\mathrm{m}$ a.s.l.). In all altitudinal zones, the majority of seedlings and saplings belonged to the deciduous pioneer species silver birch Betula pendula Roth., aspen Populus tremula L. and willow Salix appendiculata Vill. (900-1,299 m: 79.3\%; 1,300-1,699 m: $97.4 \%$ and 1,700-2,100 m: 85.3\%), while the PFSF species larch, downy oak, Scots pine and Norway spruce represented only a small portion (900-1,299 m: $12.4 \% ; 1,300-1,699 \mathrm{~m}: 2.5 \%$ and $1,700-2,100 \mathrm{~m}: 14.4 \%)$. Resprouting was very sparse and was only observed in downy oak. In contrast to tree recruitment, revegetation of the understory occurred rapidly after the fire, and the average cover of herbaceous species exceeded $60 \%$ at all but the lowest altitudes in 2007 (Fig. 2b).

The number of tree seedlings and saplings $(0-500 \mathrm{~cm})$ was neither related to the thickness of the ash layer nor to the cover of mosses (Table 1). However, seedling and sapling densities of both PFSF and pioneer species increased with altitude. While the density of PFSF species was inversely proportional to the distance to the forest edge in the first 3 years after the fire, pioneer species showed a (positive) relationship with the distance to the forest edge
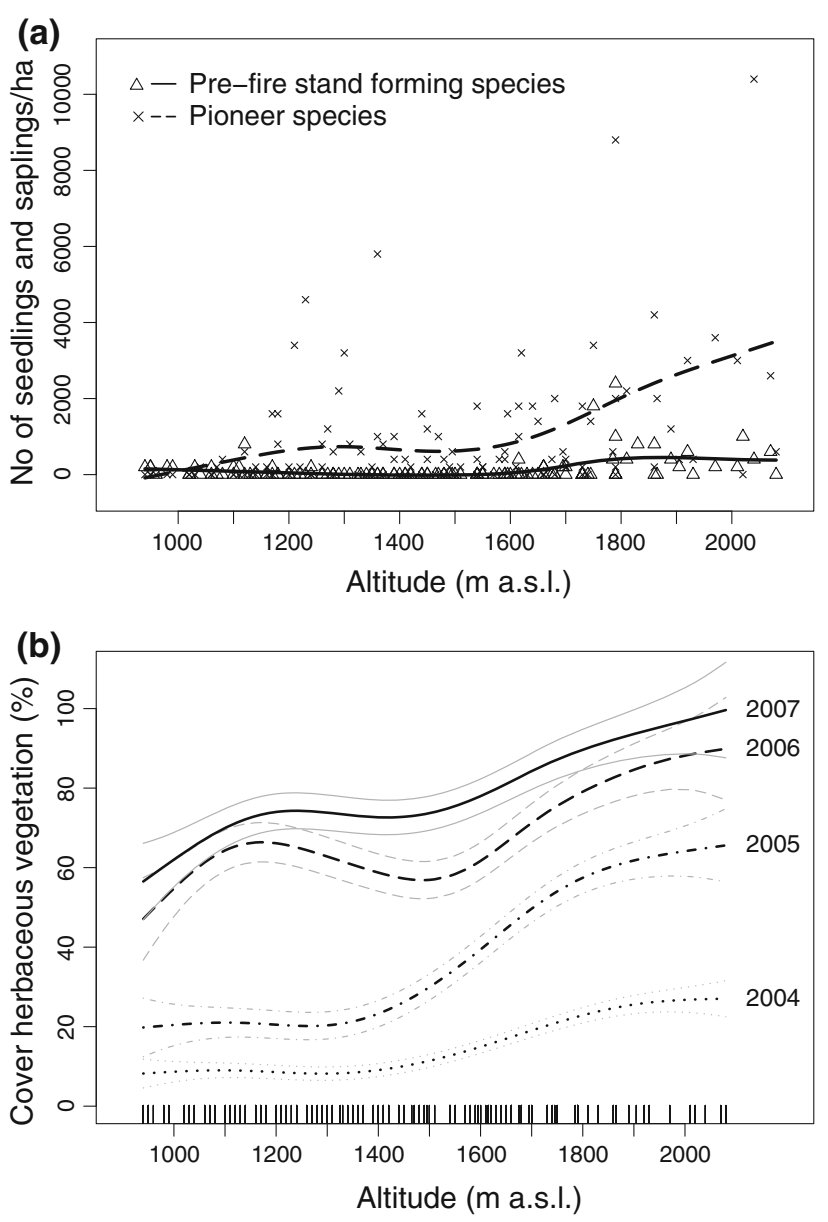

Fig. 2 a Number of seedlings and saplings $(0-500 \mathrm{~cm})$ of pre-fire stand forming and pioneer species, respectively, along the altitudinal gradient in 2007, 4 years after the stand replacing wildfire. Seedling and sapling densities along the gradient were modelled using generalized additive models (GAMs). b Revegetation at different altitudes in the first 4 years after the fire: curves represent mean cover of herbaceous species (black) $\pm \mathrm{SE}$ (light grey) modelled by GAMs. Vertical lines represent the distribution of the sampling plots along the altitudinal gradient

only in 2004. Seedling and sapling density was negatively related to the availability of exposed mineral soil in the first 3 years after the fire (PFSF: 2004-2005; pioneer species: 2005-2006).

The number of seedlings $(0-10 \mathrm{~cm})$ peaked in 2004 and then continuously decreased in the following years (Fig. 3). The abundance of tree seedlings was low in the lower and upper montane zones, but jumped in the subalpine zone. The mortality of PFSF seedlings was high in all altitudinal zones and in all years, mostly exceeding $60 \%$. By contrast, annual seedling mortality in pioneer species was mostly lower than $25 \%$ in the first 2 years (it reached $39 \%$ in the lower montane zone in the second year) but increased in the third year and reached as much as $89 \%$ in the subalpine zone. 
Table 1 Results of analysis of deviance on the effects of altitude ( $\mathrm{m}$ a.s.l.), distance to forest edge $(\mathrm{m})$, cover of exposed mineral soil $(\%)$, moss cover (\%) and thickness of the ash layer in $2004(\mathrm{~cm})$ on the number of seedlings and saplings of pre-fire stand forming species
(Larix decidua, Picea abies, Pinus sylvestris and Quercus pubescens) and pioneer species (Betula pendula, Populus tremula and Salix appendiculata), respectively, 2-4 years after the stand replacing wildfire in 2003

\begin{tabular}{|c|c|c|c|c|c|c|c|c|}
\hline \multirow[t]{2}{*}{ Variables } & \multicolumn{4}{|c|}{ Pre-fire stand forming species } & \multicolumn{4}{|c|}{ Pioneer species } \\
\hline & 2004 & 2005 & 2006 & 2007 & 2004 & 2005 & 2006 & 2007 \\
\hline Altitude & 2.177 & 1.367 & 2.461 & 4.248 & 8.405 & 2.865 & 2.509 & 3.082 \\
\hline Distance to forest edge & -4.055 & -1.536 & -3.876 & - & 2.954 & - & - & - \\
\hline Exposed mineral soil & -1.676 & -1.417 & - & 4.567 & - & -2.218 & -5.855 & - \\
\hline Moss cover & - & - & - & - & - & - & - & 1.516 \\
\hline Ash layer & - & - & - & - & - & - & - & - \\
\hline$D^{2}$ & 0.46 & 0.19 & 0.28 & 0.23 & 0.45 & 0.30 & 0.29 & 0.26 \\
\hline
\end{tabular}

Coefficients are shown for those variables included after stepwise model optimisation using standardised predictors. $D^{2}$ per cent deviance explained

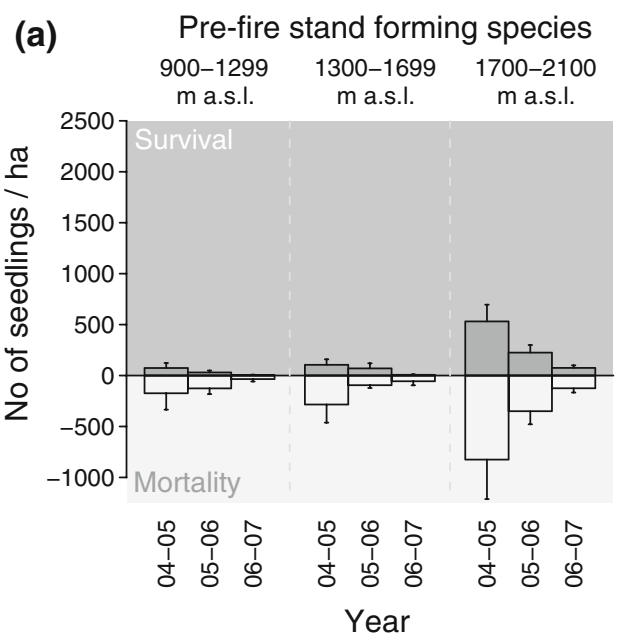

Fig. 3 Survival and mortality of tree seedlings $(0-10 \mathrm{~cm})$ along the altitudinal gradient in the first years after the fire: positive bars represent the number of seedlings survived in each period $($ mean $\pm \mathrm{SE})$, negative bars represent disappeared seedlings. The sum of the absolute values of the negative and positive bars equals the

Observations of cone production in Graechen and Gampel Steg near Leuk indicate that seeds of larch and Scots pine were available in all years, whereas Norway spruce failed to produce seeds in spring 2005 and 2006 (Table 2).

Climate along the altitudinal gradient

Air temperature and precipitation linearly changed along the altitudinal gradient within the burn (Fig. 4a and b; data shown for June only). The slopes of the regression lines were similar in all years, indicating that temperature and precipitation increments along the altitudinal gradient are reasonably constant. In June, differences in precipitation levels reached between 15 and $21 \mathrm{~mm}$ on a gradient of $1,000 \mathrm{~m}$ in the years 2005-2007, whereas temperatures

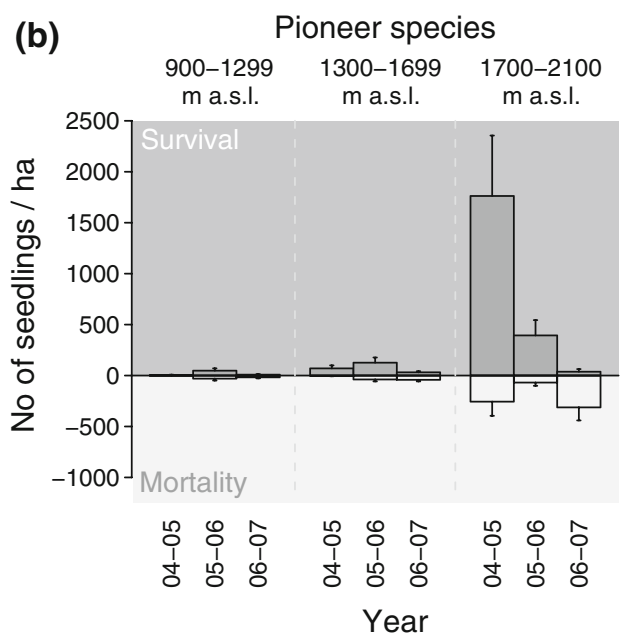

total number of seedlings present at the beginning of each period. a Pre-fire stand forming species (Larix decidua, Picea abies, Pinus sylvestris and Quercus pubescens); b pioneer species (Betula pendula, Populus tremula and Salix appendiculata)

Table 2 Cone production of Larix decidua, Picea abies and Pinus sylvestris in two regions of the Rhone valley near Leuk, Switzerland, in spring 2004, 2005 and 2006 (data provided by A. Burkart)

\begin{tabular}{lllll}
\hline Species & Region & 2004 & 2005 & 2006 \\
\hline Larix decidua & Graechen & 1 & 2 & 1 \\
Picea abies & Gampel Steg & 2 & 0 & 0 \\
& Graechen & 1 & 0 & 0 \\
Pinus sylvestris & Graechen & 2 & 1 & 3 \\
\hline
\end{tabular}

0 , no cones observed; $1,<50 \%$ of trees produced cones; $2,50 \%$ of trees produced cones; $3,>50 \%$ of trees produced cones (masting)

differed by $6.7-7.2^{\circ} \mathrm{C}$. Similar differences along the altitudinal gradient can be found in the long-term precipitation measurements at the two meteorological stations in Sierre (539 $\mathrm{m}$ a.s.1.) and Montana (1,508 $\mathrm{m}$ a.s.l.). The difference 

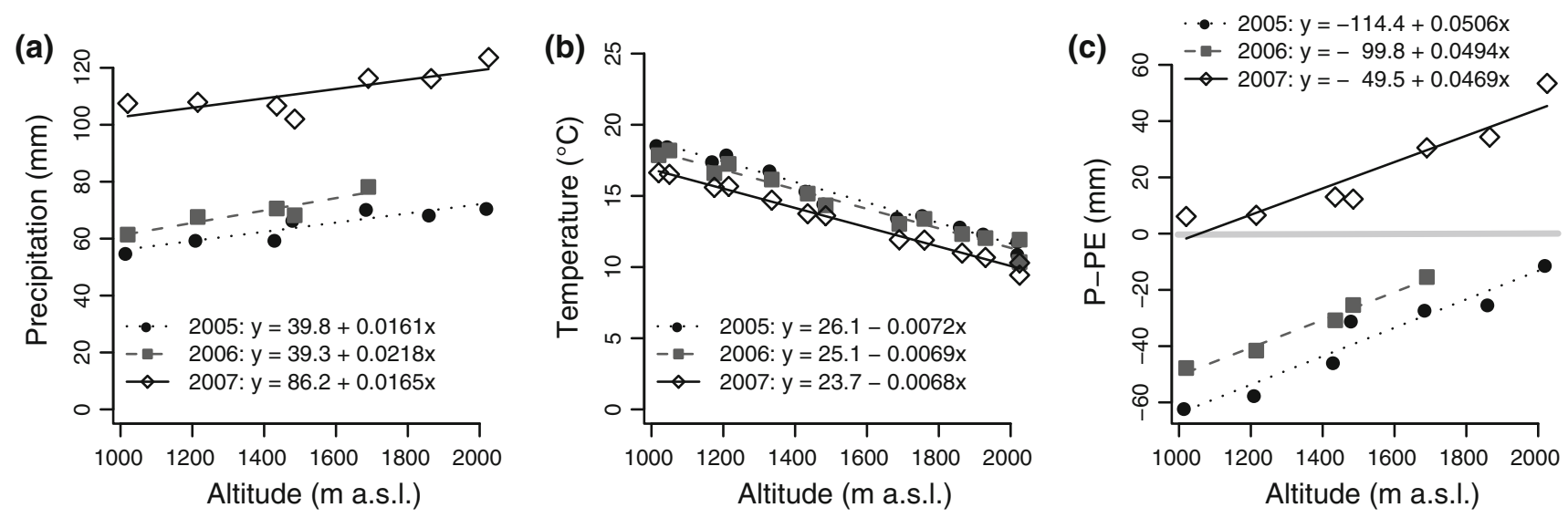

Fig. 4 Climatic differences along the altitudinal gradient in the burnt area in June 2005, 2006 and 2007. a Monthly precipitation sum; b Monthly mean temperature and $\mathbf{c}$ Drought index (precipitation-potential evapotranspiration): values below zero indicate moisture deficits

(a)
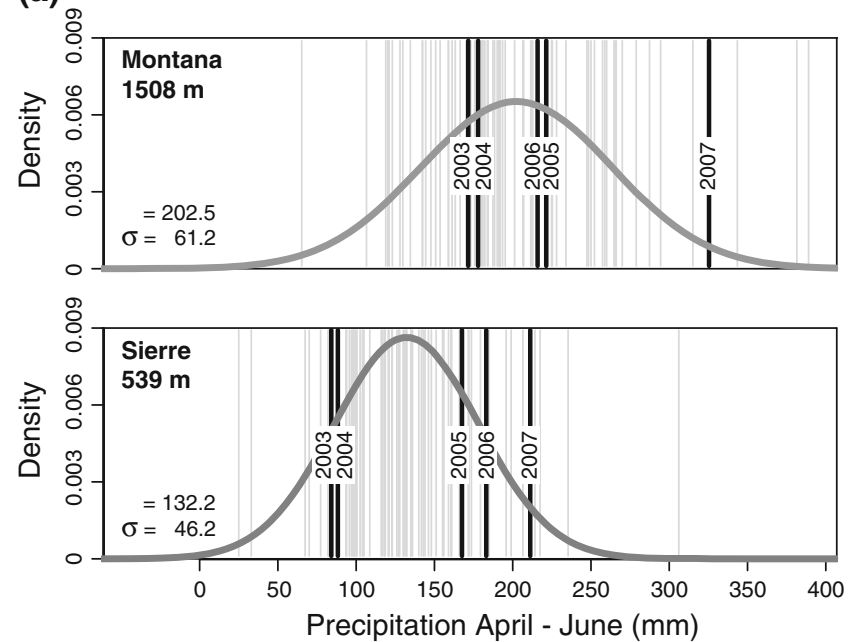

Fig. 5 Comparison of long-term precipitation levels (1931-2007) at two contrasting altitudes represented by the two meteorological stations Montana (1,508 $\mathrm{m}$ a.s.1.) and Sierre (539 $\mathrm{m}$ a.s.1.) in the vicinity of the burnt area (data from MeteoSwiss). a Spring precipitation (April-June); b annual precipitation. Vertical lines

in mean precipitation (1931-2007) between the two locations amounts to $70 \mathrm{~mm}$ in spring (April-June) and to $314 \mathrm{~mm}$ annually (Fig. 5). Even in the extremely dry year of 2003, precipitation at Montana exceeded the long-term average of Sierre (1931-2007) considerably. By contrast, the annual precipitation at Sierre did not reach the longterm average of Montana during the extraordinarily wet 2007.

The DRI showed marked differences in the amount of water available to plants along the altitudinal gradient at the end of spring (Fig. 4c). In June, water availability was $46-49 \mathrm{~mm}$ higher at $2,000 \mathrm{~m}$ than at $1,000 \mathrm{~m}$ a.s.l., depending on the year. In 2005 and 2006, years with moderately wet spring seasons (Fig. 5a), the potential evapotranspiration exceeded precipitation at 1,000 $\mathrm{m}$ a.s.l. (b)
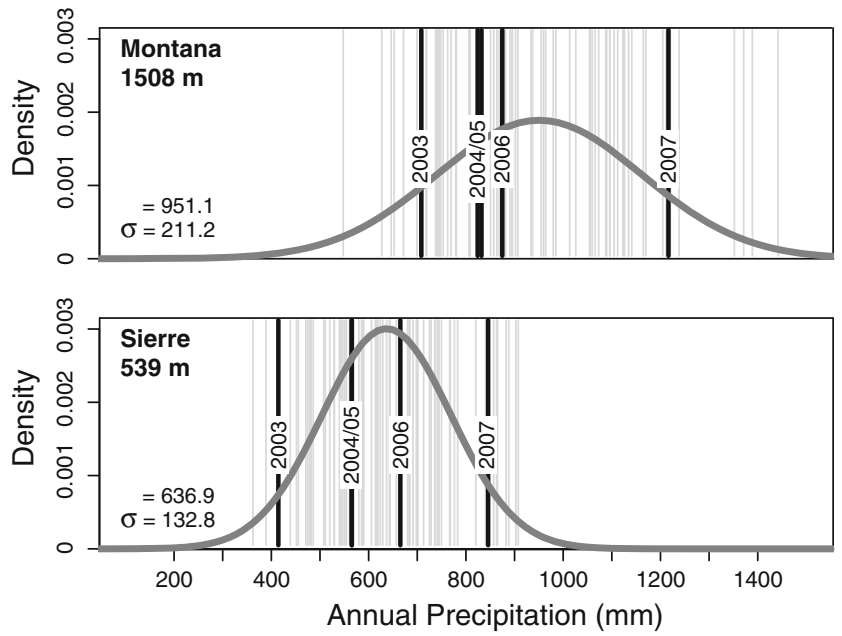

represent precipitation levels of individual years from 1931-2007, bold lines indicate the year of the burn (2003) and the first years after the fire (2004-2007). Grey curves represent a fitted normal distribution

by 48 and $62 \mathrm{~mm}$, respectively, resulting in a clear water deficit. Even in the extraordinarily wet spring of 2007, precipitation exceeded the potential evapotranspiration only marginally at the lowest altitude. At higher altitudes, water was abundant in 2007 , and the moisture deficit was small in 2005.

\section{Discussion}

During the last centuries, fire has played a minor role in shaping forest ecosystems in the Central Alpine valley of the Valais (Schumacher and Bugmann 2006), where 85\% of the fires with known source of ignition are caused by humans (Zumbrunnen et al. 2009). Nevertheless, small 
fires occur regularly in this region, and there is strong evidence that increasing temperatures and changes in forest use and management will lead to an increase in large fire events at low altitudes (Zumbrunnen et al. 2009). Modelling studies have already suggested that fire may become more important for forest dynamics in the Central Alps than changes in growth conditions due to global warming (Elkin et al. 2010; Schumacher and Bugmann 2006). Our study suggests that reforestation after large, stand replacing fires in the European Central Alps has to rely mainly on recruitment from seeds, both because high intensity fires destroy the seedling and sapling bank, and resprouting is not common in Scots pine and Norway spruce (Zasada et al. 1992). The fact that post-fire regeneration in Scots pine almost exclusively depends on seed rain from outside the burnt area is also known from Mediterranean areas (Habrouk et al. 1999). The sharp decline in the number of tree seedlings 2 and 3 years after the fire in Leuk indicates that the window of opportunity for tree recruitment is very short. This is consistent with studies in boreal forests (Charron and Greene 2002; Greene et al. 2004). The rapid spread of herbaceous species increased competition and reduced the availability of favourable seedbed (Wohlgemuth et al. 2002), which we consider to be the main reason limiting germination of tree seeds and early survival in our site 2 and 3 years after the fire. However, boreal studies suggest that the reduction in granivores by the fire may also be important (Charron and Greene 2002; Greene et al. 2004). Although short, the period of low competition after the fire was long enough for pioneer species such as aspen and willow. Their small, anemochorous seeds disperse over large distances (Braatne et al. 1996; Müller-Schneider 1986) and were thus able to reach the whole burnt area by the second year after the fire (Clark et al. 1998; McEuen and Curran 2004). By contrast, dispersal distances in the coniferous, PFSF species are smaller (Brown et al. 1988; Dovciak et al. 2008; Müller-Schneider 1986), and seed availability depends on the presence of live seed trees, as indicated by the negative correlation between the number of seedlings and saplings and the distance to the forest edge in our study (cf. Greene and Johnson 2000 and Keyser et al. 2008 for North American conifers). Moreover, seed availability in Scots pine and Norway spruce varies considerably between years (masting; Rohmeder 1972; Zackrisson et al. 1999). Since the window of opportunity for seedling establishment is short and seedling mortality was high in all years, abundant seed supply and favourable growth conditions in the first 2 years after a fire are crucial for successful tree recruitment.

Many studies in boreal forests of North America demonstrated a positive relationship between sapling density and fire intensity, which has been linked to the better performance of seedlings on soils with thin organic layers as opposed to thick organic layers present after low severity fires (Greene et al. 2007; Jayen et al. 2006; Johnstone and Kasischke 2005; Turner et al. 1997; but see Keyser et al. 2008). Similarly, exposed mineral soil is considered as favourable seedbed after disturbance in European boreal forests (Brang 1998; Valkonen and Maguire 2005; Vanha-Majamaa et al. 1996), but it has been suggested that microclimatic conditions, especially water availability, are even more important for tree recruitment than seedbed type (Oleskog and Sahlen 2000; Vanha-Majamaa et al. 1996). In our study, tree recruitment was negatively related to the availability of exposed mineral soil in the first years after the fire. In contrast to windthrow disturbance in subalpine forests, where exposed mineral soil indicates low competition (Brang 1998; Wohlgemuth et al. 2002), this seedbed type seems to provide adverse growth conditions in the first years after a stand replacing fire. Recruitment success was independent of fire intensity in our study, which may be mainly due to the fact that the fire was severe in all parts of the Leuk burn. Consequently, the variation in fire intensity may have been too small to be relevant for seed germination and seedling establishment. Contrary to fire intensity and exposed mineral soil, post-fire seedling and sapling density increased with altitude in all years and both species groups. The sparse regeneration of Scots pine at lower altitudes in Leuk contrasts with several studies reporting fast and abundant post-fire recruitment of this species in European boreal forests (Hancock et al. 2009; Östlund et al. 1997; Zackrisson 1977), where water availability is rarely a limiting factor. Temperature and precipitation measurements in our site demonstrated that moisture deficits in the second and third years after the fire were considerable at lower and medium altitudes in June, even though precipitation levels in these years were above the long-term average. At higher altitudes, however, moisture deficits were small in the same years. Consequently, years with favourable moisture conditions for seedling establishment in spring are rare at low and medium altitudes, and successful seedling establishment requires precipitation levels far above the long-term average. Thus, we suggest that drought is the key limiting factor for tree recruitment after fire disturbance in the Central Alps. This is concordant with various studies showing that water availability in spring is one of the most important factors affecting germination, seedling establishment and tree growth in Scots pine and Norway spruce (Castro 2006; Castro et al. 2005; Pichler and Oberhuber 2007; Rigling et al. 2002), the main pre-fire species at low and medium altitudes in our site. Since the rise in temperature and the prolongation of drought periods are expected to continue during the coming decades (Beniston et al. 2007; IPCC 2007), windows of opportunity for tree regeneration after fire disturbance may become 
increasingly rare at lower altitudes of the Central Alps. Scots pine forests in the lower montane zone of the Rhone valley have already been considered vulnerable to climate change because of their limited drought tolerance (Bigler et al. 2006; Rebetez and Dobbertin 2004; Weber et al. 2007). Based on observations in mature stands, Rigling and Cherubini (1999) suggested that dominant Scots pine will be replaced by the more drought-resistant downy oak with continued global change, whereas dynamic vegetation models go even further and predict the transition of these forests into steppe under climate change scenarios involving an increase in temperature of $4.7^{\circ} \mathrm{C}$ or more (Bugmann 1999). The failure of tree regeneration at lower altitudes in our study in years with precipitation levels above the longterm average indicates that such changes may be accelerated by disturbance events such as wildfires, which in turn supports the predictions by Schumacher and Bugmann (2006) and Elkin et al. (2010) that wildfires may become important for shaping forest ecosystems in the future even in areas where fire disturbance is currently low.

Acknowledgments We gratefully acknowledge field work by Sara Bangeter, Alexandra Bunge, Stefan Hadorn, Tabea Kipfer, Marlen Kube, Salome Leugger and Lukas Wohlgemuth and logistic support from Claudio Cattaneo, Dieter Trummer and Ulrich Wasem. We thank A. Burkart for providing the data on cone production, and Ilkka Vanha-Majamaa and Peter Brang for comments on the manuscript. The study was supported by the Dienststelle für Wald und Landschaft, Canton of Valais, Switzerland.

\section{References}

Attiwill PM (1994) The disturbance of forest ecosystems-the ecological basis for conservative management. For Ecol Manag 63:247-300

Badeck FW, Bondeau A, Bottcher K, Doktor D, Lucht W, Schaber J, Sitch S (2004) Responses of spring phenology to climate change. New Phytol 162:295-309

Beniston M, Stephenson DB, Christensen OB, Ferro CAT, Frei C, Goyette S, Halsnaes K, Holt T, Jylha K, Koffi B, Palutikof J, Scholl R, Semmler T, Woth K (2007) Future extreme events in European climate: an exploration of regional climate model projections. Clim Change 81:71-95

Bigler C, Bräker OU, Bugmann H, Dobbertin M, Rigling A (2006) Drought as an inciting mortality factor in Scots pine stands of the Valais, Switzerland. Ecosystems 9:330-343

Braatne JH, Rood SB, Heilman PE (1996) Life history, ecology and conservation of riparian cottonwoods in North America. In: Stettler RF, Bradshaw HD, Heilman PE, Hinckley TM (eds) Biology of Populus and its implications for management and conservation. NRC Research Press, Ottawa, pp 57-86

Brang P (1998) Early seedling establishment of Picea abies in small forest gaps in the Swiss Alps. Can J For Res 28:626-639

Brown KR, Zobel DB, Zasada JC (1988) Seed dispersal, seedling emergence, and early survival of Larix laricina (Duroi) K. Koch in the Tanana Valley, Alaska. Can J For Res 18:306-314

Brzeziecki B, Kienast F, Wildi O (1995) Modelling potential impacts of climate-change on the spatial-distribution of zonal forest communities in Switzerland. J Veg Sci 6:257-268
Bugmann H (1999) Anthropogene Klimaveränderung, Sukzessionsprozesse und forstwirtschaftliche Optionen. Schweiz Z Forstwes 150:275-287

Castro J (2006) Short delay in timing of emergence determines establishment success in Pinus sylvestris across microhabitats. Ann Bot 98:1233-1240

Castro J, Zamora R, Hodar JA, Gomez JM (2004) Seedling establishment of a boreal tree species (Pinus sylvestris) at its southernmost distribution limit: consequences of being in a marginal Mediterranean habitat. J Ecol 92:266-277

Castro J, Zamora R, Hódar JA, Gómez JM (2005) Alleviation of summer drought boosts establishment success of Pinus sylvestris in a Mediterranean mountain: an experimental approach. Plant Ecol 181:191-202

Chapin FS, Callaghan TV, Bergeron Y, Fukuda M, Johnstone JF, Juday G, Zimov SA (2004) Global change and the boreal forest: thresholds, shifting states or gradual change? Ambio 33:361-365

Charron I, Greene DF (2002) Post-wildfire seedbeds and tree establishment in the southern mixedwood boreal forest. Can J For Res 32:1607-1615

Clark JS, Macklin E, Wood L (1998) Stages and spatial scales of recruitment limitation in southern Appalachian forests. Ecol Monogr 68:213-235

Dale VH, Joyce LA, McNulty S, Neilson RP, Ayres MP, Flannigan MD, Hanson PJ, Irland LC, Lugo AE, Peterson CJ, Simberloff D, Swanson FJ, Stocks BJ, Wotton BM (2001) Climate change and forest disturbances. Bioscience 51:723-734

Dovciak M, Hrivnak R, Ujhazy K, Gomory D (2008) Seed rain and environmental controls on invasion of Picea abies into grassland. Plant Ecol 194:135-148

Elkin C, Weibel P, Bugmann H (2010) Zukünftiges Waldbrandrisiko. In: Leben mit Waldbrand. Merkblatt für die Praxis. Eidg. Forschungsanstalt für Wald, Schnee und Landschaft WSL, Birmensdorf, pp 13-14

Greene DF, Johnson EA (2000) Tree recruitment from burn edges. Can J For Res 30:1264-1274

Greene DF, Noel J, Bergeron Y, Rousseau M, Gauthier S (2004) Recruitment of Picea mariana, Pinus banksiana, and Populus tremuloides across a burn severity gradient following wildfire in the southern boreal forest of Quebec. Can J For Res 34:18451857

Greene DF, Macdonald SE, Cumming S, Swift L (2005) Seedbed variation from the interior through the edge of a large wildfire in Alberta. Can J For Res 35:1640-1647

Greene DF, Macdonald SE, Haeussler S, Domenicano S, Noel J, Jayen K, Charron I, Gauthier S, Hunt S, Gielau ET, Bergeron Y, Swift L (2007) The reduction of organic-layer depth by wildfire in the North American boreal forest and its effect on tree recruitment by seed. Can J For Res 37:1012-1023

Habrouk A, Retana J, Espelta JM (1999) Role of heat tolerance and cone protection of seeds in the response of three pine species to wildfires. Plant Ecol 145:91-99

Hancock MH, Summers RW, Amphlett A, Willi J (2009) Testing prescribed fire as a tool to promote Scots pine Pinus sylvestris regeneration. Eur J For Res 128:319-333

Hanssen KH (2003) Natural regeneration of Picea abies on small clear-cuts in SE Norway. For Ecol Manag 180:199-213

Henig-Sever N, Poliakov D, Broza M (2001) A novel method for estimation of wild fire intensity based on ash $\mathrm{pH}$ and soil microarthropod community. Pedobiologia 45:98-106

IPCC (2007) Climate change 2007: the physical science basis. WMO, Geneva

Jayen K, Leduc A, Bergeron Y (2006) Effect of fire severity on regeneration success in the boreal forest of northwest Quebec, Canada. Ecoscience 13:143-151 
Johnstone JF, Chapin FS (2006) Fire interval effects on successional trajectory in boreal forests of northwest Canada. Ecosystems 9:268-277

Johnstone JF, Kasischke ES (2005) Stand-level effects of soil burn severity on postfire regeneration in a recently burned black spruce forest. Can J For Res 35:2151-2163

Jump AS, Hunt JM, Penuelas J (2006) Rapid climate change-related growth decline at the southern range edge of Fagus sylvatica. Glob Change Biol 12:2163-2174

Keyser TL, Lentile LB, Smith FW, Shepperd WD (2008) Changes in forest structure after a large, mixed-severity wildfire in ponderosa pine forests of the Black Hills, South Dakota, USA. For Sci 54:328-338

Krüssmann G (1983) Handbuch der Nadelgehölze. Parey, Berlin

Kullman L (2002) Rapid recent range-margin rise of tree and shrub species in the Swedish Scandes. J Ecol 90:68-77

Linderholm HW (2006) Growing season changes in the last century. Agric For Meteorol 137:1-14

Londo G (1976) Decimal scale for releves of permanent quadrats. Vegetatio 33:61-64

McEuen AB, Curran LM (2004) Seed dispersal and recruitment limitation across spatial scales in temperate forest fragments. Ecology 85:507-518

Müller-Schneider P (1986) Verbreitungsbiologie der Blütenpflanzen Graubündens. Veröff Geobot Inst ETH Stift Rübel Zürich 85:1263

Oleskog G, Sahlen K (2000) Effects of seedbed substrate on moisture conditions and germination of Scots pine (Pinus sylvestris) seeds in a mixed conifer stand. New For 20:119-133

Östlund L, Zackrisson O, Axelsson AL (1997) The history and transformation of a Scandinavian boreal forest landscape since the 19th century. Can J For Res 27:1198-1206

Ott E, Frehner M, Frey HU, Lüscher P (1997) Gebirgsnadelwälder. ein praxisorientierter Leitfaden für eine standortgerechte Waldbehandlung, Paul Haupt, Bern

Overpeck JT, Rind D, Goldberg R (1990) Climate-induced changes in forest disturbance and vegetation. Nature 343:51-53

Payette S, Filion L, Delwaide A, Begin C (1989) Reconstruction of tree-line vegetation response to long-term climate change. Nature 341:429-431

Peñuelas J, Ogaya R, Boada M, Jump AS (2007) Migration, invasion and decline: changes in recruitment and forest structure in a warming-linked shift of European beech forest in Catalonia (NE Spain). Ecography 30:829-837

Pichler P, Oberhuber W (2007) Radial growth response of coniferous forest trees in an inner Alpine environment to heat-wave in 2003. For Ecol Manag 242:688-699

R Development Core Team (2006) R: a language and environment for statistical computing. R Foundation for Statistical Computing, Vienna

Rebetez M, Dobbertin M (2004) Climate change may already threaten Scots pine stands in the Swiss Alps. Theor Appl Climatol 79:1-9

Rigling A, Cherubini P (1999) Wieso sterben die Waldföhren im 'Telwald' bei Visp? Schweiz Z Forstwes 140:113-131

Rigling A, Braker O, Schneiter G, Schweingruber F (2002) Intraannual tree-ring parameters indicating differences in drought stress of Pinus sylvestris forests within the Erico-Pinion in the Valais (Switzerland). Plant Ecol 163:105-121

Rodríguez-Pérez J, Traveset A (2007) A multi-scale approach in the study of plant regeneration: finding bottlenecks is not enough. Perspect Plant Ecol Evol Syst 9:1-13

Rohmeder E (1972) Das Saatgut in der Forstwirtschaft. Paul Parey, Hamburg

Schär C, Vidale PL, Lüthi D, Frei C, Häberli C, Liniger MA, Appenzeller C (2004) The role of increasing temperature variability in European summer heatwaves. Nature 427:332-336
Schmidli J, Frei C (2005) Trends of heavy precipitation and wet and dry spells in Switzerland during the 20th century. Int J Climatol 25:753-771

Schumacher S, Bugmann H (2006) The relative importance of climatic effects, wildfires and management for future forest landscape dynamics in the Swiss Alps. Glob Change Biol 12:1435-1450

Sykes MT, Prentice IC (1996) Climate change, tree species distributions and forest dynamics: a case study in the mixed conifer northern hardwoods zone of northern Europe. Clim Change 34:161-177

Sykes MT, Prentice IC, Cramer W (1996) A bioclimatic model for the potential distributions of north European tree species under present and future climates. J Biogeogr 23:203-233

Tercero-Bucardo N, Kitzberger T, Veblen TT, Raffaele E (2007) A field experiment on climatic and herbivore impacts on post-fire tree regeneration in north-western Patagonia. J Ecol 95:771-779

Thornthwaite CW (1948) An approach toward a rational classification of climate. Geogr Rev 38:55-94

Thuiller W (2003) BIOMOD—optimizing predictions of species distributions and projecting potential future shifts under global change. Glob Change Biol 9:1353-1362

Thuiller W, Lavorel S, Sykes MT, Araujo MB (2006) Using nichebased modelling to assess the impact of climate change on tree functional diversity in Europe. Divers Distrib 12:49-60

Tinner W, Conedera M, Ammann B, Lotter AF (2005) Fire ecology north and south of the Alps since the last ice age. Holocene 15:1214-1226

Turner MG, Romme WH, Gardner RH, Hargrove WW (1997) Effects of fire size and pattern on early succession in Yellowstone National Park. Ecol Monogr 67:411-433

Valkonen S, Maguire DA (2005) Relationship between seedbed properties and the emergence of spruce germinants in recently cut Norway spruce selection stands in southern Finland. For Ecol Manag 210:255-266

Vanha-Majamaa I, Tuittila E, Tonteri T, Suominen R (1996) Seedling establishment after prescribed burning of a clear-cut and a partially cut mesic boreal forest in southern Finland. Silva Fenn 30:31-45

Walther GR (2003) Plants in a warmer world. Perspect Plant Ecol Evol Syst 6:169-185

Weber P, Bugmann H, Rigling A (2007) Radial growth responses to drought of Pinus sylvestris and Quercus pubescens in an innerAlpine dry valley. J Veg Sci 18:777-792

Wohlgemuth T, Kull P, Wütrich H (2002) Disturbance of microsites and early tree regeneration after windthrow in Swiss mountain forests due to the winter storm Vivian 1990. For Snow Landsc Res 77:17-47

Wohlgemuth T, Duelli P, Ginzler C, Gödickemeier I, Hadorn P, Hagedorn F, Küttel P, Lüscher P, Moretti M, Schneiter G, Sciacca S, Wermelinger B (2005) Ökologische Resilienz nach Feuer: Die Waldbrandfläche Leuk als Modellfall. Schweiz Z Forstwes 156:345-352

Zackrisson O (1977) Influence of forest fires on north Swedish boreal forest. Oikos 29:22-32

Zackrisson O, Nilsson MC, Jaderlund A, Wardle DA (1999) Nutritional effects of seed fall during mast years in boreal forest. Oikos 84:17-26

Zasada JC, Sharik TL, Nygren M (1992) The reproductive process in boreal forest trees. In: Shugart HH, Leemans R, Bonan G (eds) A system analysis of the global boreal forest. Cambridge University Press, Cambridge, pp 85-125

Zumbrunnen T, Bugmann H, Conedera M, Bürgi M (2009) Linking forest fire regimes and climate-a historical analysis in a dry inner alpine valley. Ecosystems 12:73-86 